\title{
ANTIHUMANISM ILMA RESERVITA: NALJA FUNKTSIOON JA HÄVITUSE MÕõTMED (:)KIVISILDNIKU VIIMASE AJA LUULES
}

\author{
NEEME LOPP
}

\section{Kivisildniku luule lähtepositsioon}

$\mathrm{M}$ illalgi selle sajandi esimese kümnendi keskel muutis Kivisildnik oma luuletajanime (:)kivisildnikuks ja millalgi siis toimus tema luules ka märgatav teisenemine. Nimelt suunas ta oma kõnelejapositsiooni energia formaalsete kirjanduskonventsioonide (mis on üleüldse luule? kuidas kirjandusruumis käitutakse?) ründamiselt normatiivsema (kirjandus)poliitika ajamisele (milline on hea luule? milline on õige elu?), tehes seda siiski endale omase vastandumis- ja ümberpööramistehnika kaudu. Seda muutust on ka varem tähele pandud, kirjeldades seda Kivisildniku luulekeele selginemise terminites (vt Luks 2014), mille kolm peamist tunnust võiks kokku võtta järgmiselt: 1) pöördumine ilma algupärata intertekstuaalsuse juurest selge autorihäälega manifestatiivse lausumise poole; 2) mängulise kerguse asendumine apokalüptilise tõsidusega; 3) ajatuse vahetamine päevakajaliste teemade vastu (Luks 2014: 87-88).

Selles võib näha ka Kivisildniku luuletajapositsiooni kindlustumist, omamoodi etableerumist või kanoniseerumist - nähtust, mille vastu ta ise on pealtnäha alati väga pühendunult võidelnud. Enam pole tal vaja muretseda oma koha pärast eesti kirjandusloos, nüüd võib saavutatud positsiooni muudel eesmärkidel kasutama hakata ja rääkida sellest, mis tegelikult südamel, pealegi normaalsel ja selgel moel. Nagu Kivisildnik isegi hiljuti ühes intervjuus tõdes: „Mingi piirini on kontseptuaalsus viljakas, mingist piirist alates enam mitte" (Kivisildnik 2016: 26). Teisisõnu, kui tahta toota tõeliselt funktsionaalset teksti, peab abstraktsus paratamatult mingil määral taanduma ja luulekeel selginema.

Kuid kellega see selginenud luulekeel kõneleb, kellele ta on adresseeritud? Sellele vastamiseks tuleb esmalt panna paika Kivisildniku kõne lähtepunkt, mida saab kõige täpsemini kirjeldada negatiivse positsioonina. See tähendab, et Kivisildniku kõne lähtepunkt postuleerib ennast selgeimalt läbiva vastandumishoiakuna, mis omandab tema luules teksti üles ehitava rolli. Seetõttu võib eitust pidada ka tema tekstide struktuuriliseks paratamatuseks. Kivisildnik vastandub oma tekstis justkui kõigele, mis pürib püsivama sotsiaalse ja kultuurilise tähenduse poole ja kinnistub nii masside argiteadvusse, vastandub igasugusele ühiskondlikult domineerivale positsioonile. Vastandumine on siin nagu puhas vorm, tühi kest, mille puhul pole oluline, millise sisuga see täidetakse. Nii on Kivisildnikul võimalik korraga vastanduda ka omavahel tavamõttes vastandlikele nähtustele, näiteks nii traditsioonile kui ka uuendusele; miski ei ole Kivisildniku tekstuaalsesse masinavärki sattudes kaitstud antagoniseerimise eest. 
Kajar Pruul kirjeldab seda negatiivset positsiooni järgmiselt:

Kivisildniku omamüüt rajaneb äraspidisel geeniusekujul, kes seisab teispool head ja kurja. See kuju ühendab endas korraga nii avangardistliku kunstiheerose, ketserliku usukannataja kui ka kunsti kaubastamise ajastu küünilise müügimehe ja meediafiguuri omadusi. Kõik need jooned on paisutatud paroodilisuseni ning kunagi ei või teada, millised neist ja missuguses kombinatsioonis parajasti esile paisatakse. (Pruul 2000: 199)

Varasemas luules läks Kivisildniku vastandumisstrateegia sedavõrd kaugele, et tekst hakkas vastanduma isegi tähendusele kui sellisele, liikudes lausungiterviku lõhkumise kaudu asemantikasse: „riisiviin nagu / oleks lihunik varba / küüsi lakkinud” (Kivisildnik 1996: 240). Sellise luule kaasaegne paariline eesti kirjanduses on Erkki Luugi luule. Uuel sajandil aga Kivisildniku luule lihtsustub ning ka vastandumine toimub formaalsema keeletasandi asemel suuremate ideede pinnal, avangardistikuju taandub ja esile tõuseb rohkem usukannataja tahk.

Ometi tundub, et sellise vastandumistaktika puhul ei ole tegu patoloogiaga, vaid see on programmiline pragmaatiline hoiak, mis puudutab nii kirjandusruumi toimimisloogikat kui ka inimese käitumispsühholoogiat laiemalt. Tegu on provokatsiooniga, lihtsa võttega tõmmata endale ja oma tekstidele tähelepanu. Sest kui tekstid ei saa tähelepanu, siis mis mõte oleks neid üldse kirjutada? Seejuures on tähelepanu tõmbamiseks lubatud kõik vahendid, eesmärk pühitseb igal juhul abinõu. Kivisildniku trikk seisneb selles, et ehkki küünilisuses ja mässus pole tänapäeva kultuuris enam ammu midagi uut, sisaldab see ometi „mingit ligitõmmet”, isegi kui mässaja ei mõju enam kangelasena, vaid on lihtsalt naljakas (vt Mihkelev 2003: 865).

Kivisildnik ise nimetab provokatsiooni standardlähenemiseks: see on „üks lihtsamaid viise, kuidas natukene värvi lisada” (Kivisildnik 2016: 26). Sellega selgineb ka Kivisildniku luuleteo esmane adressaat: selleks on provokatsiooni objekt, see, kes provokatsiooniga kaasa läheb, isegi mitte mingi kindel isikuline rünnakuobjekt, vaid reaktsioon kultuuris kui sellises. Seejuures ei näi provokatsioon üldsegi üksnes leebe „värvilisamisena”, vaid on tungiline reaktsioon sellele, et provokaator tunneb sellesama kultuuri sees ahistust (Freudi mõttes) ja kompenseerib seda. Millisel moel see kompenseerimine täpsemalt realiseerub, seda eritlen allpool. Oluline on hetkel välja tuua, et sellisele ebaisikulisele reaktsioonile apelleerimine tundub olevat üks põhjuseid, mis on muutnud hinnangute andmise Kivisildniku provokatsioonidele kohalikus kultuuriruumis komplitseerituks. Kriitika on kaldunud tekstides ilmnevaid rünnakuid pigem vabandama, lahjendama või nägema neid kultuuriliselt konstruktiivse ja vabastavana, välistades sellega rünnakute põhimõttelise pahatahtlikkuse, autori kibestumuse vms. Nii taandatakse Kivisildniku tekstide transgressiivne vaim esteetikale, leksikale, poeetikale vms, muutes selle transgressiivsuse loomuliku kirjandusakti osaks (vt nt Kalda 1996; Pruul 1996). Tundub, et kriitika ei suuda määratleda, mis on rünnaku objektiks, kriitiku halvustav hinnang võiks paljastada tema enda naeruväärsuse ning see muudab tema seisukohad ebalevaks ja ettevaatlikuks. Kriitika reaktsioonide lahkamine kujutab endast tegelikult tervet eraldi uurimisteemat, mis võiks Kivisildniku fenomeni avamisel kirjandusruumis olla äärmiselt põnev ja viljakas. 
Niisiis, veel kord kokku võttes: Kivisildniku luulemina poodiumiks, millelt kõne lähtub ning mis määratleb selle kõne modaalsuse, on kõike eitav hoiak, mis põhineb provokatsioonil ja mida põhjustab provokaatori ahistus kultuuris. Hasso Krull on Kivisildniku rohked vastandumised koondanud kolme „anti-” abil: antilürism, antiintellektualism ja antihistorism (vt Krull 2015: 49). Selles artiklis tahaksin ma lisada neile veel ühe - antihumanismi -, mis kerkib eriti esile tema aastail 2011-2013 ilmunud kogudes: nn valuraamatute triloogia „Liivlased ja saurused” (2011), koostöös Navitrollaga ilmunud „(:)soari evangeelium” (2012) ja „Inimsööja taksojuht” (2013), samuti nende vahele jääv kogu „Enne sõda ja kõike seda” (2012).

Tekib õigustatud küsimus, miks piiritletakse siinses artiklis antihumanismiga just see periood, mitte nt Kivisildniku eelmise sajandi intertekstuaalne „masinaluule”, mis kehastab iseeneses antihumanismi vast tugevamaltki. Formaalseks põhjuseks võib pidada seda, et pädevaid sissevaateid Kivisildniku varasema tekstiloome masinlikkusse on eesti kirjandusteaduses juba varem ilmunud (vt Krull 1990, 1997; Pilv 1997a, 1997b, 2002 jt). Sisuliseks põhjuseks on aga see, et soovin siin pöörata tähelepanu just järjepidevalt referentsi tasandil väljendatavale antihumanistlikule positsioonile, selgelt jälgitavale sõnumile, mis annab aimu Kivisildniku tekstis väljendatava inimesesuunalise hävituskujutluse mõõtmetest. Ning fookuses olevates kogudes on antihumanistlik paatos manifestatiivse sõnumi tasandil kõige selgemini välja joonistatud. Manifestatiivse sõnumi edastamiseks ongi vajalik selgepiirilisem lüüriline subjekt, mille esilekerkimisele käesoleva sajandi esimese kümnendi keskel viitas Kivisildniku luulekeele selginemist käsitledes ka Leo Luks (vt 2014: 87).

Järgnevates luulekogudes antihumanistlik ideoloogia taandub veidi ning Kivisildnik hakkab omandama rohkem koolmeistri, koolkondliku käilakuju ja staarkirjastaja rolli. Antihumanistliku programmiga, millel puudub igasugune tulevikuvisioon, koolkonda ei suurenda.

\section{Ideoloogia - humanism - antihumanism}

Ideoloogia defineerin siinse artikli tarbeks järgmiselt: ideoloogia on see, kui maailmas asetleidvatele protsessidele antakse tähendus mingi implitsiitsena kasutatava kimbu ideede, uskumuste ja väärtuste kaudu, mis hakkavad ennast esitama reaalsuse, paratamatuse, ajaloo, mõistuspära jm „loomuliku” aluse ja sihina. Ideoloogiliseks ei tee mingit väidet, ettepanekut vms niisiis mitte see, et väitele on püütud anda mingi püsivam tähendus ja mõte (muidu oleks iga lause maailmas ideoloogiline ja ideoloogia mõiste hajuks laiali), vaid totaalsus, mis on ideoloogilise väite horisont ja mis muudab sellesse väitesse puutuvad igasugused juhuslikud parameetrid oma paratamatuks funktsiooniks. Millegi teeb ideoloogiliseks iseeneslik aluseksasetumise akt, sattumuslikkuse taandamine. Ideoloogia on alati aktiivne.

Nii on kommunistlik ideoloogia selline kimp ideid, mis näitab töölisklassi revolutsiooni, võimuletulekut ning töölisklassi korraldatud ja valitsetud maailma kogu ajaloo paratamatu ja loogilise arenguna, mis tuleneb olemasolevate tootmissuhete paratamatust arengust ja ümberkorraldamisest. Iga maailmas toimuva protsessi elementi on võimalik näha mõistuspäraselt selle arengu mingi faasina. Kusjuures selleks, et olla efektiivne, peab ideoloogia 
seesmine toimemehhanism - see, kuidas miski meelevaldne ja juhuslik naturaliseeritakse, mõtestatakse loomuliku ja paratamatuna - jääma ise nähtamatuks. Kummatigi vastab see ka Karl Marxi arusaamale ideoloogiast, mida ta käsitles Saksa ideoloogia näitel negatiivses võtmes nn valeteadvusena, näidates, kuidas kapitalistlik loogika katab ideoloogilisi võtteid kasutades kinni ja surub alla ühiskonna „loomulikke” arenguid. Seevastu kommunistlik areng on loomulik ning võorandamata tootmissuhted ei varja oma loogikas midagi. Selline positsioon on muidugi juba ise ideoloogia kõige puhtam näide.

Kas humanism on ideoloogia? Muidugi. Humanism on ideoloogia, mis esitab üksikisiku väärtust, vaba tahet ja tema otsust toimida efektiivsuse eesmärgil kollektiivina kui ajalooliste protsesside loomuliku toimimise alust ja sihti. Humanismi seisukohast on inimkond jõudnud seisundisse, kus ta suudab ise ennast transtsendeerida ja leida iseendas oma moraali ja käitumise aluse. Isegi kui sekulariseerimine pole veel nii kaugele jõudnud, peaks üksikisiku väärtus olema vähemalt ajalooliste protsesside ülim siht. Niisiis ühelt poolt vabad indiviidid juba teostavad seda arengut, teiselt poolt tuleb tõeliselt vaba inimeseni alles jõuda, tuleb tema poole püüelda.

Kivisildniku puhul on mõtet rääkida antihumanistlikust vastuideoloogiast, kuna see põhineb olemasoleva humanistliku positsiooni õonestamisel sellele koherentset ja positiivsetes terminites määratletavat ideoloogilist programmi asemele pakkumata. Antihumanistlikku positsiooni ei tasu segi ajada posthumanismiga, mis püüab eneseküllast arusaama inimolust küll vaidlustada, kuid teha seda olemasolevat inimesekirjeldust nü an s s e erides, nt lisades inimese kirjeldusse ka tema hõlmatuse tehnoloogilisse maailma ja üldistesse prosteetilistesse arhiveerimismehhanismidesse, mis on tavapärasest inimesepildist väljaspool, kuid millega sümbioosis tema inimlikkus on sündinud (vt Wolfe 2010: xv). Antihumanism soovib aga olemasoleva inimesekirjelduse ühel või teisel viisil ületada, näidata, et inimlikkuse asemel tegutseb inimese keskmes loom, masin, struktuur vms.

Kivisildniku antihumanistliku vastuideoloogia eesmärk ongi eelkõige humanistliku illusiooni biologistliku ja kommertsiaalse aluspõhja välja toomine: kõikide humanistlike müütide taga ei ole muu kui lääne kaubandushuvid; inimeste „vaba tahte” realiseerimise tulemusel ei ülendu nad paremateks inimesteks, vaid hoopis alanduvad tarbimiselajateks ning nende vaimne võimelisus kuhtub; humaanse moraali asemel allub üksikindiviid loomalikule karjainstinktile. Seetõttu sobib inimese tegutsemist Kivisildniku luules kõige paremini kirjeldama animaalne metafoorika (selle kohta vt ka Kaus 2013). Ometi joonistatakse lääne kultuuris sellisele „loomastumisele” pähe üksikisiku eneseteostuse humaanne nägu. Tavapärane arusaam kultuurist muutub seega illusoorseks, kuna see, mida peetakse kultuuriks, devalveerub kaubandussuhete mõjul kiiresti massikultuuriks, mida iseloomustab individuaalse mõtlemisvõime puudumine, ühesõnaga kõik, mis vastandub humanismi ideaalile. Siit tuleneb ka Kivisildniku antikultuurilisus: ei vastanduta mitte kultuurile kui sellisele, vaid enamuse kultuurile.Keskpärane kirjanik ja kultuur on Kivisildnikule jälk (vt nt pikemat luuletust „Põis ei põle ära”, Kivisildnik 2013: 36-40).

Milleks meile rahvuslik ülevustunne ja rituaalid? Pole vaja lehvitada lippe, kui me vaatame läbi samade silmade sellesama naudinguga, kuidas lehvivad juuksed šampoonireklaamis. Kivisildniku luulemina ei võta seejuures silmakirjalikku poosi. Kaubandustööstusliku maailma ihamasin läbistab meie elusid sel määral, et meil ei jää midagi muud üle kui seda kõike nautida. 
Kuid ärgem tehkem siis seejuures nägu, et me täidame mingit humaanset agendat, tunnistagem ausalt, et me pole seda tehes paremad lojustest ning meil polegi õigust nõuda endale midagi enamat kui pangalaenuorjus. Kui ideoloogia määratlusse oli sisse kirjutatud, et selle seesmine toimemehhanism peab jääma nähtamatuks, siis vastuideoloogia mõte on just selle nähtamatuks jääva küünilise tuuma paljastamine.

\section{Prohvetlik kõne, manifestatiivsus}

Antihumanistlikuna saab tõlgendada juba Kivisildniku selgepiirilisemat lüürilist subjekti ennast, kes hakkab omandama lausa prohvetlikke mõõtmeid. ${ }^{1}$ Prohveti iha on suunatud inimlikust sfäärist väljapoole - kuna tal on kontakt üleinimliku sfääriga, asubki prohvet õigupoolest juba otsapidi teispool inimsust, mis annab tema kõnele suurema tõelisuse astme. Prohveti kõne eemaldab keelest inimliku ekslikkuse, seega inimlikkuse kui sellise, kui peame ekslikkust üheks inimese olemuslikuks mõõdupuuks (Errare humanum est!) selles puudub arvamine, on üksnes teadmine, puudub näivus, on üksnes tõde. Selle tulemusel pole prohvet „eriti palju inimene”, vaid ta üritab olla „võimalikult vähe inimene”, otse (jumalikku) tõde kuulutav meedium, algoritm vms. Kui Kivisildnik postuleerib 1997. aastal ilmunud värssromaani „Loomade peal katsetatud inimene” tagakaanel, et „lõppudelõpuks on luule / see mis mina ütlen", siis kümme aastat hiljem oleks sobivam lugeda seda avaldust vastupidi: mina ütlen, mis see luule lõppude lõpuks on, sest mina ei ole üks inimene teiste seas, vaid mu kõne tuleb teiselt poolt inimlikkust. Ideaalis ei pakugi selline luule ennast üldse esteetilisele otsustusvõimele, vaid see on võimalik lihtsalt vastu võtta või eemale lükata.

Seega pöördub Kivisildnik mitmeski mõttes (taas) traditsioonilise modernistliku avangardi poole, millega ta programmiliselt flirtis ka 1980. aastate lõpus ja 1990. aastate alguses (vt Kivisildnik 1990a, 1990b; Navitrolla jt 1993 jm; väga põhjaliku ingliskeelse käsitluse tolle perioodi avangardistlike nähtuste kohta Eestis on kirjutanud Tiit Hennoste (2012)). Ta manifesteerib mingit luulekäsitust ning kõik muud kirjanduse kirjutamise viisid on selle visiooni kõrval ühel või teisel viisil ebaõiged. Klassikalisele avangardistlikule kirjandusele omaselt (vt Hennoste 2016) võib manifest siin kerkida olulisemakski kui kirjandustekst ise, kuuludes samaväärselt kirjandusteo juurde. On väga kõnekas, et Kivisildnik ei tee oma loomeprotsessist saladust, vaid laob, vastupidi, lugejale kõik välja. Need ei ole lihtsalt kommentaarid selle kohta, kuidas luule on komponeeritud või kuidas luulet tuleks kirjutada, vaid on ise orgaaniline kirjanduslik action (vt Hennoste 2016).

Luule, mis manifesteeritud reeglite vastu eksib, ei kuulu elusate ega heade kultuuriväärtuste hulka. Siin ilmneb Kivisildniku luulekäsituse normatiivne jäikus, mistõttu suurem osa Eesti oleviku ja mineviku luuleloomingust ei osutu mitte üksnes väärtus etuks luuleks, vaid ei osutu üleülds e luuleks. Mis omakorda tähendab, et ajaloo jooksul on Eestis statistiliselt loodud väga vähe, peaaegu kaduvväike hulk luulet - väide, millega Kivisildnik asetab ennast ühe hoobiga väljapoole eesti luuletraditsiooni. Ometi on ta ju ise kasutanud

${ }^{1}$ Kivisildniku tekstuaalset sugulust Vana Testamendi prohvetitega täheldas Hasso Krull juba 1997. aastal (vt Krull 1997: 170). 
oma luule materjalina pidevalt eesti luule traditsiooni ning ühes eelviidatud artiklis (Luks 2014) on teda käsitletud isamaaluuletajana. Kivisildniku „isamaavajadus” ja vajadus selle isamaa identiteedi alustalasid õõnestada ei lähe aga kuidagi omavahel vastuollu, vaid seesmine paradoksaalsus on tema strateegiale olemuslik. Lühidalt, luuletraditsiooni valdamine on tema puhul vajalik selle traditsiooni kastreerimiseks, mitte orgaaniliseks jätkamiseks. Just hävituse kaudu on võimalik jõuda sellise isamaa ja isamaalisuseni, mille järele Kivisildnik ihaleb. Paradoksaalsus seisnebki aga selles, et tema hävituslik lähenemine realiseerub lõpuks ikkagi sellesama isamaa vajadusena, mida esmalt hävitada püütakse.

Aga mida Kivisildnik siis manifesteerib? Iseenesest ei midagi uut, mida ei saaks seostada tema varasema kirjandustegevusega. Ta manifesteerib, et vaba tahte, tunnete ja inimlikkuse asemel peavad luulet juhtima kood, tehnika ja (masinlik) funktsionaalsus (vt lähemalt Kivisildnik 2015). Luule peab olema algoritmipõhine, mitte lähtuma isiklikest tundevirvendustest, just seetõttu on ta tõene. Algoritm ei saa petta, sest see on huvitu, eneseväljenduse plaanis tulevad mängu aga inimese psühholoogilisest profilist tulenevad isiklikud kaalutlused, millega teistel inimestel ei ole asja.

Erinevus varasemate manifestidega on selles, et kui „Märja Viktori” aegse Kivisildniku puhul oli algoritmi kasutamise eesmärk rünnata kehtivaid kirjanduskonventsioone ehk teksti hävituslik potentsiaal oli suunatud kirjanduse suhtes väljastpoolt sissepoole, siis nüüd on kirjandusmanifestis kuulutatu selgemalt kooskõlas mingi kirjandusvälise sõnumiga, mida ma siinse artikli kontekstis nimetan Kivisildniku antihumanistlikuks vastuideoloogiaks ning mis toimib kirjanduse suhtes suunaga seestpoolt väljapoole. Seega, kui Kivisildniku kirjanduslik võttestik on alati sporaadiliselt edendanud antihumanistlikke ideid, siis nüüd saavad need endale taha püsivama autorihääle, kes need ideed koherentsemalt sõnadesse paneb.

\section{Paar märkust Kivisildniku luuletehnikast}

Millist tehnikat Kivisildnik vastuideoloogilise toime saavutamiseks kasutab? Vastuideoloogi roll on kultuuris iseeneslikult toimivat tähendusprotsessi kuidagi destabiliseerida, seada küsimuse alla selle eneseküllane alus. Samal põhimõttel töötas ka Roland Barthes oma väikekodanlike argimüütide analüüsis, aga Kivisildniku lähenemine on palju tehnilisem. See tehnika on püsinud Kivisildnikul suures plaanis muutumatuna kogu loomingu vältel. Tähenduse destabiliseerimine toimib mingi ümberpööramisvõtte kaudu ning see ümberpööramine võib toimuda eri tekstitasanditel. Ümberpööramise saavutamiseks tuleb ilma narratiivse põhjenduseta tuua luuletusse kokku tähenduslikud elemendid, mis tavamõistuse järgi kuuluvad eri süsteemidesse, kuid mis külgnemise tõttu hakkavad looma võrdusi, üksteisele lähenema, omandama mingit sarnasust, kusjuures elementide omavaheline erinevus võib ilmneda nii semantilisel, stilistilisel kui ka foneetilisel tasandil. Nagu märkas juba Roman Jakobson: kõik positsiooniliselt lähestikku asuvad elemendid hakkavad kirjanduses lähenema ka semantiliselt (vt Jakobson 2012: 1757 jj).

Toon mõned üsna puhtakujulised tekstinäited nende erinevuste kohta. 
(1) Erinevus semantilisel tasandil.

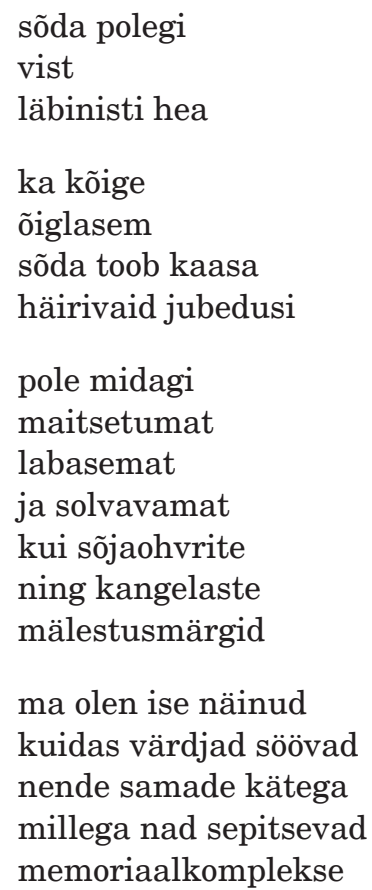

(Kivisildnik 2012: 36-37)

Siin tuuakse kokku kaks semantilist režiimi, mis tavamõistuse seisukohalt kuuluvad täiesti eri maailma: sõjajubeduste kole, maine ja efemeerne maailm kohtub mälestusmärkide „kauni”, püha ja püsiva maailmaga; Kivisildnik sooritab ümberpööramisvõtte ning vahetab neile režiimidele tavapäraselt omistatavad omadused omavahel ära. Koledus, maisus ja efemeersus kuulub nüüd mälestusmärkidele, samal ajal kui sõda on kaunis ja püha. Tundub iseenesestmõistetav, aga tasub siiski eraldi väljatoomist.

Semantilise erinevuse efekt võib põhineda ka metafoori pööramisel luuletuse käigus.

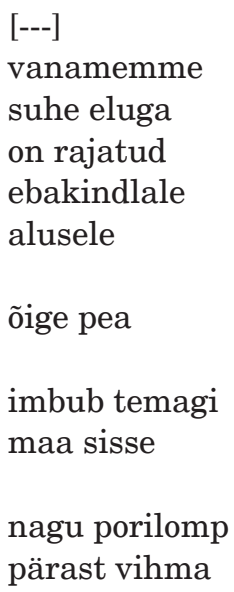

(Kivisildnik 2011: 11) 
Väljend „ebakindel alus”, mis allub esiti traditsioonilisele metafoorsele lugemisele, pööratakse värsiga „maa sisse” ümber, võimaldades hoopis teist laadi võrdlusi ja semantikat (surm, vanainimeste väärtus ühiskonnas jm). Samasugust võtet kasutas oma luules tihti Jüri Üdi. ${ }^{2}$

(2) Erinevus stilistilisel tasandil, mis põhjustab omakorda erinevust semantilises režiimis.

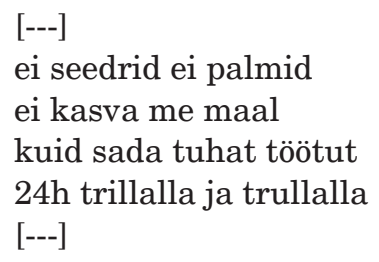

Siin pannakse korraga kõnelema mitu erinevat stiiliregistrit: rahvuslikromantiline, proletaarne-rahvalik, poliitilis-bürokraatlik jmt. Tulemuseks on see, et üheski registris lausutut ei saa võtta enam tõsiselt, rahvusliku õhkamise paatos madaldatakse.

(3) Erinevus foneetilisel tasandil, mis põhjustab erinevusi ka stilistikas ja semantikas (nt ,jihaadimees” pro „paadimees”). Selle puhtaim näide tuleb Kivisildniku varasemast luulest.

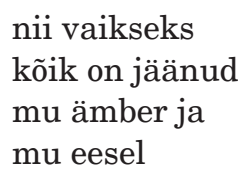

(Kivisildnik 1996: 787)

Väikese foneetilise muudatusega muutub nii luuleteo stiil kui ka laiem semantiline kontekst, mis seab muu hulgas kahtluse alla inimhinge pühaduse, mis võiks ilmneda justkui ainult sisekaemuse vaikuse südames. Sealt, kus peaks helisema hing, kostab ämbrikolinat.

Nagu näha, esinevad need erinevused gradatsioonilises suhtes, kus väiksemate üksuste erinevused sisalduvad suuremate üksuste erinevuses või tekitavad seda otseselt, nii et peamiselt toimivad kõik erinevustasandid korraga ja segamini.

kus on minu pommivöö kus on minu moonipõld kõik mis põleb on ainult väikse varga ökotõld [---] (kivisildnik, navitrolla 2012: 13)

\footnotetext{
${ }^{2}$ Selle tähelepaneku eest võlgnen tänu artikli retsensendile.
} 
Eriti toimib vastandamine nn kõrge ja madala representatsiooniregistri kõrvutamise puhul, mis paljastab antagonismide kunstlikku hierarhiat kõige efektiivsemalt. See, mida ühiskonnas peetakse väärtuseks, osutub seeläbi mitteväärtuseks ja vastupidi. Tuleb muidugi nentida, et selline representatsioonilise harjumuse häirimine ongi suurema osa luule eesmärk, Kivisildnik kasutab seda lihtsalt niivõrd tehniliselt, skemaatiliselt, antagonismidega opereerides ja nende osiseid vahetades, et seda pole võimalik ega üritatagi varjata.

Ümberpööramisele lisaks toimib Kivisildniku luules programmilise madaldamise printsiip, mis kõlab tema kirjanduse vastandumispoliitikaga hästi kokku. 2013. aasta Vikerkaares ilmunud arvustuses Valdur Mikita „Lingvistilisele metsale" selgitab Hasso Krull Mikita Eesti-müüdi loomist retoorilise võttega, mida ta nimetab meioosise kustutamiseks. Üldjoontes tähendab see seda, et võetakse peavoolukultuuris ringlevad meioosised („Eesti on nii väike”, „eesti keel on vaene”, „Eesti ajalugu on igav”, „Eesti kultuurkiht on liiga õhuke” jmt) ning pööratakse need ümber, asendades meioosise jõulise hüperbooliga, kus Eesti osutub ürgse loomismüüdi epitsentriks, kus võib korraga kogeda nii elu kui ka universumi algupära (vt Krull 2013: 152-153). Kivisildnik pöörab selle mehhanismi omakorda ümber: ideoloogilise hüperbooli asendab ta litootesega, lõputu vähendamisega.

\author{
oh jah \\ jaapan on \\ kaugel \\ eesti võiks \\ ka natuke \\ kaugemal olla
}

(kivisildnik, navitrolla 2012: 61)

\title{
Nali ja selle funktsioon
}

Üllatuse, ümberpööramise ja litootese rakendamise tulemus on tihti koomilise efektiga. Kivisildniku tekstid mõjuvad tihti, nagu teeks autor nalja, isegi kui see nali tundub liiga mõru. See on äärmiselt oluline, kindlasti üks olulisemaid Kivisildniku luuletegevuse iseloomujooni, mida on varem Keeles ja Kirjanduses iroonia mõiste kaudu veidi puudutanud Anneli Mihkelev (2003), veelgi varem aga Piret Noorhani (1998). Aare Pilv pühendas oma 2016. aasta juunikuus Underi ja Tuglase Kirjanduskeskuses peetud teadusseminari Kivisildniku transsarkasmi teemale.

Miks on nali ja selle funktsioon Kivisildniku puhul niivõrd oluline? Vaatame ühte nalja määratlust: „Nali on vahend, millega subjektid kompenseerivad oma „ahistust” kultuuris,” kirjutab Jaanus Adamson. „Põhimõtteliselt on nali üleastumine ja kähkukas: mingi nn "tendentsliku” (reeglina sündsusetu, küünilise vms) tõe ootamatu vilksatus, lühike „patu” hetk, mille lunastuseks on - nalja onnnestumise korral - auditooriumi kohene naer (mitte hilinenud tõsimeelne arutlus)." (Adamson 2015: 50) Kui Kivisildniku luule realiseerub tihti naljana, siis võib eeldada, et see luule on kõneleja kultuurilise ahistuse sümptom, selle kompensatsioonimehhanism; ning selle nalja tulemusel vilksatab mingi tendentslik, nt sündsusetu või küüniline tõde. Kuid tundub, et Kivisildniku tekstides tuleb nalja funktsioneerimise põhjuslikku 
ahelat lugeda n-ö tagurpidi. Neis ei tehta esmajoones nalja, mis tooks kõrvalsaadusena kaasa mingi kokkuleppeliste reeglite suhtes sündsusetu tõe, vaid kuna „tõde”, mida need tekstid ennekõike tahavad ilmutada, ongi tavamõistuse suhtes sündsusetu, obstsöönne, küüniline, ropp vmt, pole seda üleüldse võimalik ilmutada teisel viisil kui nalja vormis. Ühtegi teise vormi ei mahu see tõde ära, üheski teises vormis see ei kommunikeeru.

Seetõttu on oluline mitte võtta neid tekste üksnes naljana, st vähendada nende sisu ja taandada see ebaoluliseks kui pelgalt nali. Sigmund Freud tõdes nalja funktsioone uurides järgmist. Seal, kus nali ei ole eesmärk iseeneses (st süütu), „asub ta vaid kahe tendentsi teenistusse, mida saab ühendada ühe vaatepunkti alla; ta on kas vaenulik nali (mis teenib agressiooni, satiiri, tõrjumist) või rõve nali (mis teenib paljastamist). [---] Üldiselt vajab tendentslik nali kolme isikut, lisaks sellele, kes teeb nalja, teist, kes võetakse kas vaenuliku või seksuaalse rünnaku objektiks, ja kolmandat, kellele on suunatud nalja naudingu tekitamise kavatsus. [---] Muutes vaenlase väikeseks, madalaks, põlastusväärseks, koomiliseks, loome kaudselt selle ületamisest naudingu, mida kolmas isik, kes ei ole mingit vaeva näinud, kinnitab meile oma naeruga." (Freud 2008: 114, 118, 122) Kivisildniku tekstides pole nali eesmärk iseeneses (peen intellektuaalne huumor), vaid sündsusetu ja küünilise tõe esiletoomise eesmärk on kastreerida see, kelle pihta nali on suunatud, kolmanda osapoole juuresolekul, kes saab sellest naudingut (naerab). ${ }^{3}$

Kivisildniku luules, kus nali ei ole eraldi eesmärk, on seega mõlemal tendentsil (vaenulikkus ja rõvedus, mille efekt on agressioon ja paljastamine) oluline roll. See ilmneb juba kõnekujundi tasandil: Kivisildniku nali on alati sarkastilise, mitte iroonilise iseloomuga. See ei ole varjatud pilge (iroonia), kõigile kolmele osapoolele peab olema täiesti selge, keda rünnatakse. Tegu on avaliku kastratsiooniga, mis võtab naeruvääristamise kaudu rünnatavalt ära tema ihaobjekti (keelab talle selle), vabanedes nii tema autoriteedi survest ja asendades selle omaenda kõnelejapositsiooni autoriteediga, mille seisukohta enam ei vaidlustata; ning see asendus tekitab luule tegelikus sihtmärgis (lugejas) naudingut.

Kivisildniku luule kui „tendentsliku tõe ootamatu vilksatus” tähendab ka seda, et see tuleb justkui keele-eelsest sümboliseerimatust Reaalsest enesest ${ }^{4}$ (Jacques Lacani mõttes), mis teisisõnu tähendab: võimatusest enesest. See tuleb ennasttühistavalt positsioonilt, mida sümboolses korras justkui ei tohikski olemas olla.

$$
\begin{aligned}
& \text { [---] } \\
& \text { kui inimkond } \\
& \text { aimaks mu } \\
& \text { olemasolu }
\end{aligned}
$$

\footnotetext{
${ }^{3}$ Raamatus „See õige luuleõpik” laiendab (:)kivisildnik selle strateegia üleüldse kõikide tõeliste luuletajate intentsiooniks: „poeedi eesmärk on lugeja kastreerimine” (Kivisildnik 2015: 219).

${ }^{4}$ „Kivisildniku taotluseks on lüüa diskursiivsesse reaalsusesse mõra, kiskuda lahti lõhe, millest meile äkki avaneks Reaalne ilma ühegi sümboolse maskeeringuta" (Krull 1997: 169-170).
} 
kui ta ainult

aimaks oleksin

ma juba surnud

ammu

surnud

surnud veel

enne sõda

(Kivisildnik 2012: 29-30)

Selline paradoksaalsus on Kivisildniku luulele väga omane. 2014. aasta juubelikonverentsil aset leidnud avalikus diskussioonis selgitas autor ise, et tal ongi kombeks olnud seada endale ülesandeid, mida on võimatu lahendada. Võimatus ülesannet täielikult sooritada kuulub nende südamesse. Antihumanistliku Kivisildniku seisukohalt on tegu väga olulise, võib isegi öelda otsustava märkusega. Tal puudub igasugune positiivne tulevikuvisioon, kuulutus tulevasest inimesest või elukorraldusest: tema võimalikkuse tingimus on ühtlasi tema võimatuse tingimus.

\section{Hävituse mõõde}

Antihumanistlikud suundumused on lääne mõtteloos idanenud mitmel rindel. Kõigepealt on olemas mitmesuguseid katseid ületada inimene lähtuvalt jumala hülgamisest: biologism (me kõik pole enamat kui loomad), kognitivism (meie tegevust juhib üksnes arvutav mõtteprotsess, millele me ekslikult omistame käitumuslikke omadusi, n-ö vaba tahet) jt. Teiseks on olemas suundumused, mida tuntakse 1960. aastate prantsuse teoreetilise antihumanismina ning mis tulenevad Marxi taastõlgendamisest. Need uurivad, kuidas ideoloogia toimib konkreetsetes materiaalsetes praktikates (ideoloogiliste riigiaparaatide ja repressiivsete riigiaparaatide töö) ning kuidas inimese tähendus sõltub vaid rollist, mida ta neis praktikates täidab, mitte temast enesest. Kolmandaks võib tuua tehnitsistliku transhumanismi, mis tuleneb küberneetikast (ja filosoofilisemalt juba XX sajandi alguse vene biokosmismist) ja kuulutab, kuidas me tehnoloogilise arengu tõttu läheneme uuele inimsuse tasandile, kus me pole enam inimesed selles mõttes, mida selle all tavaliselt silmas peetakse. Sellesse valda kuuluvad nähtused alates biotehnoloogiast ja tehisintellektist kuni inimese ja arvuti hübriidsuseni ning ideeni, et inimese võiks laadida internetti, ühesõnaga igasugused surematuseotsingud tehnoloogia kaudu.

Viimase variandina väärib eraldi mainimist ökoloogiline reduktsionistlik antihumanism, mille aluseks on arusaam, et inimene on vaid üks privilegeerimatu elusolend teiste seas (või, olenevalt programmist, isegi teistest väiksemate privileegidega). Ainult oma kõrkuse tõttu peab ta end teistest ülemaks, mistõttu tuleb seda kõrkust mingite vahenditega kärpida. Kõige radikaalsemana esindab sellist mõtteviisi ökoterrorism ja üllatuslikul kombel on just see Kivisildniku antihumanistlikule programmile kõige lähemal. Täpsemalt ilmneb see tal biologistlikule alusele toetuva ökoterrorismi ehk bioterrorismina. Suurem osa ökoloogilisest antihumanismist on seisukohal, et kui teha mõningaid parandusi ja kui inimesed muutuksid teadlikult mõõdukaks, on võimalik 
inimese ja looduse vaheline tasakaal säilitada. Aga on ka radikaalsem arusaam, mille järgi see ei ole võimalik, ning uue, parema situatsiooni tekkimiseks on vaja mingit väiksemat või suuremat katastroofi. „Inimese surmal” on nii pragmaatiline (inimene teeb igal juhul liiga palju kahju ökosfäärile) kui ka moraalne põhjendus (inimene on juba nii palju elukeskkonda rikkunud, et see on talle õiglane palk). See katastroof ongi Kivisildniku sõnadega „ilus sõda”, sellisel sõjal oleks mingi mõte, lihtlabane väljasuremine on üksnes „värdjatele”.

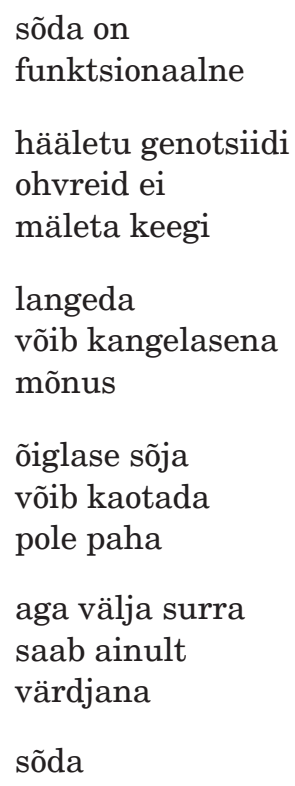

(Kivisildnik 2012: 56)

ma räägin sõjast

nagu allergiast

tegelikult

ma kardan

kardan

kohutavalt

et riigitegelased

jäävad ellu ja

muud sellised

ja hea sõda

läheb kaduma

kardan et

sõda kaotab

mõtte

ja sihi

nagu

sinu riik

(Kivisildnik 2012: 18-19) 
Tegu on Kivisildnikule üleüldse väga omase kujundi, oksüümoroni ehk paradoksaalse positsiooniga: selleks et inimene saaks normaalselt edasi elada, elada edasi inimesena, tuleb ta hävitada; ta peab kaduma, sest praegune situatsioon ei ole mingi tõeline elu. Sotsiaalne elu on niikuinii tapmine ja piinamine, ainult „seaduslikult / ent liiga tüütult” (Kivisildnik 2013: 27), seetõttu ongi pomm hea, põrgutuli sõbralik. Pangalaenud ja muu selline pudipadi ei kuulu tõelise inimese juurde, kuid neist on võimalik lahti saada ainult inimese täieliku kaotamise hinnaga, ei mingit kompromissi, kompromiss on lõks. Peavalu vastu aitab ainult giljotiin. See on antihumanism ilma reservita, ilma pääsemislootuseta valitud vähestele. Kui kristlik moraal ütleb: „sul ei ole õigust tappa”, siis Kivisildniku tekst ütleb: „sul ei ole õigust ellu jätta”. See on antihumanistliku Kivisildniku eetiline juhtmõte. Varem teostas Kivisildnik terrorit kirjandusliku tekstuaalsuse tasandil - mõtleme kas või tema esimesele luulekogule „Märg Viktor”, mis miksis automaatselt ja meelevaldselt Underi „Eelõitsengut” ja suvalisi ridu eesti triviaalsemast luulest à la Minni Nurme -, nüüd aga viidatakse terrorile väljaspool teksti: tekst peab referentsi tasandil nõudma kogu humanistliku eksistentsi hävitamist, muud moodi pole võimalik igal tasandil valitsevast mandumisest pääseda. Selles ongi Kivisildniku antihumanismi paradoksaalsus: tema võimalikkuse tingimus on ühtlasi tema võimatuse tingimus. Et inimene vabastada, peab tema inimeseksolemise pealesunnitud tuum hävinema, mida on kõige lihtsam täide viia kogu inimkonna hävitamisega. Käsi, mis luulet kirja paneb, kustutab ennast samaaegselt.

Ometi jääb tekst alles, see ei haihtu meie silmade ees. See on tunnistajaks püstitatud ülesande võimatusest. Eitus on niivõrd läbiv, et see eitab ka visiooni kohest teostumist, selle visiooni teostumine on esialgu peatatud. Kivisildniku antihumanistlik luule toimib omamoodi hoiatustekstina, mis sellisena viib ellu oma varjatud positiivset programmi. Kuni sellel on lugeja, tähendab see, et kuulutatud visioon ei ole veel täielikult teostunud. Ja kui ei oleks enam lugejat, siis oleks luules visandatu järelikult teoks saanud, tegelikustunud, väljunud kirjanduslikkuse ruumist tegelikkusse. See luule hoiatab lugejat, et kui ka lugeja alla annab ja prohvetlikku sõnumit kuulda ei võta, siis teostub luules kirjeldatud hävituslik mõõde täies mahus.

Lugeja olemasolu ongi niisiis see, mis hoiab kirjeldatut täielikult teostumast. Tekib paradoksaalne olukord: kuni leidub lugeja, on luules lausutu sõnasõnalises mõttes mittetõene, moonutatud tõde, nali; kui neid lauseid aga enam keegi ei loeks, oleks lausutu osutunud tõeks ja see ei oleks enam naljakas. See ei tähenda, et hävitus ja terror oleksid kuidagi lahjendatud; et me saaksime öelda, et hävitus on ainult sümboolsel tasandil. Ei, Kivisildniku hävituse tõelisus seisneb just nimelt selles, et see ei ole lõplikult teostunud. Mis on üks reaalne pomm? See ei ole midagi, pomme plahvatab ikka aeg-ajalt ja elu läheb edasi. Aga Kivisildniku hävitus on horisondina per m a n e n tn e, pidevalt väesolev hävitus. See viitab võimalusele, et näilisest elavusest hoolimata võivadki ülejäänud inimesed olla ju ba su rn ud, olla juba hävinenud, vähemalt ajusurnud (inimese elusoleku hindamise üks kriteeriume on ajutegevuse olemasolu), elu ongi juba lakanud. Ainult nende luuleridade lugeja on veel jäänud, olles justkui selle hävitusliku horisondi poole igavesti teel. 
(:)ood ellujäämisele

inimväärset palka

pole mul vaja

toppige see endale

inimväärset pensioni

pole mul vaja

toppige see endale

inimväärset peavarju

pole mul vaja

toppige see endale

aga mul on väga vaja

kreeka võlakirju

kolme miljardi eest

muidu ma suren

mul on vaja miljoneid

aafrika elusid päästa

muidu ma suren

ja mul on kohe vaja

uut suurt raudteed

kasutu vana raudtee

kõrvale tolmu koguma

muidu ma suren

kuidagi ei tahaks surra

ehkki ma pole noor ega

rikas ega parketile naelutatud

aga ikkagi olen ma pigem

solidaarne elavatega

kõigi nendega

kes on koomas

äärekosmos

29.06.2015-30.06.2016

(Kivisildniku Facebooki konto)

\section{Kirjandus}

Ad a m s o n, Jaanus 2015. Freudi häda. Kirjutisi 2004-2013. Tartu: EYS Veljesto Kirjastus.

Freud, Sigmund 2008. Nali ja selle seos teadvustamatusega. Tlk Mari Tarvas. Tallinn: Tänapäev. 
Hennoste, Tiit 2012. Ethno-Futurism in Estonia. - International Yearbook of Futurism Studies, kd 2, nr 1, lk 253-285.

Hennoste, Tiit 2016. Eestlased on silmapaistev manifestirahvas. [Intervjuu Pille-Riin Larmile.] - Sirp 18. III.

Jakobson, Roman 2012. Lingvistika ja poeetika. Tlk Neeme Lopp ja Arne Merilai. - Akadeemia, nr 10, lk 1731-1773.

Kalda, Maie 1996. Kivisildniku kirjanike nimekiri - mis see on? - Keel ja Kirjandus, nr 11, lk 760-764.

Ka u s, Jan 2013. Meisterlik seestunu. - Vikerkaar, nr 9, lk 94-97.

Kivis ild nik 1990a. Etnofuturismi ideaalid; Metodoloogilisi marginaale. - Vikerkaar, nr 5, lk 40-42.

Kivisildnik 1990b. Hüübinud vere manifest. - Vagabund, nr 1.

Kivisildnik 1996. Nagu härjale punane kärbseseen. Tallinn: EK\$ kirjastus.

Kivisildnik 1997. Loomade peal katsetatud inimene. Tartu: Brain Publishing.

Kivisildnik 2011 = (:)kivisildnik, Liivlased ja saurused. Valuraamatu I köide. Pärnu: Ji.

Kivisildnik 2012 = (:)kivisildnik, Enne sõda ja kõike seda. Saarde-Pärnu: Ji.

Kivisildnik 2013 = (:)kivisildnik, Inimsööja taksojuht. Valuraamatu III köide. Saarde-Pärnu: Ji.

Kivisildnik 2015 = (:)kivisildnik, See õige luuleõpik. Saarde-Pärnu: Ji.

Kivisildnik 2016. See kümnend andnud mureväsind hääle. Intervjuu (:)kivisildnikuga. Küsis Joosep Susi. - Müürileht, aprill, lk 26-27.

Kivisildnik, Navitrolla 2012. (:)Soari evangeelium. Valuraamatu II köide. Saarde-Pärnu: Ji.

Kr u ll, Hasso 1990. Põhi/pind all/peal. - Keel ja Kirjandus, nr 4, lk 250-252.

Kr u 1l, Hasso 1997. Iseenda värske õhu käes: Kivisildniku masinad ja kristallid. - Vikerkaar, nr 1-2, lk 162-170.

Krull, Hasso 2013. Lugu mehest, kes kukkus oma sokiauku. - Vikerkaar, nr 10-11, lk 151-163.

Kr u ll, Hasso 2015. Aristokraat, proletaarlane, eremiit. Kolm poeetilist hoiakut. - Vikerkaar, nr 12, lk 45-56.

Luks, Leo 2014. Isamaavajadus 25 aastat hiljem. Svenile juubeliks. - Keel ja Kirjandus, nr 4, lk 81-98.

Mihkelev, Anneli 2003. Ecce homo - Kivisildnik. - Keel ja Kirjandus, nr 11, lk 865-867.

Navitrolla, Roosimölder, Kivisildnik 1993. „LÜLITI” manifest. - Sirp 19. II, lk 12.

No orhani, Piret 1998. Kanooniline Kivisildnik. - Keel ja Kirjandus, nr 4, lk 236-241.

Pilv, Aare 1997a. Kirjandus kui tehe. - Vikerkaar, nr 1-2, lk 161-162.

Pilv, Aare 1997b. Kivisildnik versus Under. - Keel ja Kirjandus, nr 7, lk 444-448.

Pilv, Aare 2002. Kivisildniku „Liivlased” kirjandusdiskursuse sündmusena. A. Pilv, Kadri Tüür, Sündmus. Koht. (Collegium Littrarum 15.) Tallinn: Underi ja Tuglase Kirjanduskeskus, lk 8-64.

Pru u 1, Kajar 1996. Kivisildniku „Leksikon” kui kunstiteos. - Vikerkaar, nr 7, lk 66-74.

Pru ul, Kajar 2000. Vana sajandi uued luuletajad. - Varjatud ilus haigus. Valik sajandilõpu eesti luuletajaid. Koost K. Pruul. Tartu: EK\$, lk 175-207.

W olfe, Cary 2010. What is Posthumanism? Minneapolis-London: The University of Minnesota Press. 


\section{Antihumanism without reserve: the function of jokes and the dimension of destruction in the recent poetry of (:)kivisildnik}

Keywords: Estonian poetry, $21^{\text {st }}$ century, antihumanism, ideology, humour, poetics, psychoanalysis

In keeping with Kivisildnik's disposition of construing poetry, which opposes any socially or culturally dominant value or meaning, his poetry of the first half of the current decade - especially in the collections Liivlased ja saurused („Livonians and dinosaurs”, 2011), (:)soari evangeelium („The Gospel of (:)soar”, 2012) published in collaboration with Navitrolla, and Inimsöoja taksojuht („The man-eating taxidriver”, 2013), but also Enne sõda ja kõike seda („Before the war and all this”, 2012) - strikes the eye with some antihumanist traits. Although Kivisildnik's palette of literary devices had always implicitly spoken of antihumanist ideas („machine poetry"), the above collections mark a transition from implicit antihumanist pathos to a nearly explicit programme, which could as well be called an antihumanist counter-ideology.

The mission of Kivisildnik's antihumanist counter-ideology is to reveal the biologist and commercial foundation of the humanist illusion, i.e. to unfold the covert cynical core of humanism. To achieve this aim, Kivisildnik uses the reversal technique, creating a comical effect. The fun, however, is not innocent, as it enjoys seeing its object as small, low and despicable by exchanging an ideological hyperbole for a litotes, thus performing a symbolic neutering of the object.

With the same purpose in mind the author is trying to neuter the humanist image of man, the core of which is human free will. However, this leads us to Kivisildnik's paradox: the condition of the possibility of his vision is also the condition of its impossibility. As long as there are readers of that poetry the realisation of Kivisildnik's vision of total destruction must be still a little away. Yet, with no more readers around the prophecy must have been realised. Thus, the poetry referred to above manifests itself as a kind of text of warning, with a constantly haunting menacing potential on its limits.

Neeme Lopp (b. 1980), University of Tartu, doctoral student; Estonian Academy of Arts, publisher, neeme@ut.ee 